\title{
PENGARUH KEADAAN DIRI, UNSUR PENYOKONG DAN FAKTOR DEMOGRAFI TERHADAP TEKAD KEWIRAUSAHAAN MAHASISWA PENDIDIKAN TINGGI DI PROVINSI RIAU
}

(The Effect of Self-Condition, Supply Elements and Demographic Factors on the Entrepreneurship of Higher Education Students in Riau Province)

\author{
Oleh: Sukarni ${ }^{*)}$, Norasmah Othman $\left.{ }^{* *}\right)$ \\ Email: sukarni269@gmail.com
}

*) Dosen FKIP Universitas Islam Riau

**) Dosen Fakulty Pendidikan Universiti Kebangsaan Malaysia

\begin{abstract}
This study identifies factors that influence the determination of entrepreneurial. There are five for influence elements of determination entrepreneurial: self-efficacy, achievement motivation, facilitates capital, social relationships and entrepreneurial knowledge. A questionnaire was distributed to 389 university students. Finding shown that the majority of students agreed that entrepreneurial knowledge, self-efficacy, achievement motivation and facilitates capital of key factors do influenced entrepreneurial determination. AMOS path analysis was used to identify the contribution of the direct and indirect influence of the five dimensions of entrepreneurial determination. Several hypotheses have been tested and found that entrepreneurial determination influenced by entrepreneurial knowledge, self-efficacy, achievement motivation and facilitates capital. However, gender, financial support and group activities did not moderate the entrepreneurial determination, whereas student residence do moderate to entrepreneurship determination. Furthermore, selfefficacy do moderated by gender, student residence and group activities, but financial support do not moderate self-efficacy. Gender, student residence, financial support and group activities did not moderate achievement motivation. Finally the study proposes guidelines to develop an effective entrepreneurship curriculum for university in the Riau Province.
\end{abstract}

Key words: entrepreneurial determination, self-efficacy, achievement motivation, facilitates capital, social relationships, student residence, entrepreneurial knowledge

\section{PENDAHULUAN}

Kewirausahaan merupakan satu bidang yang penting bagi sesebuah negara. Budaya makan gaji dapat dikikis dalam kalangan rakyat melalui Kewirausahaan, dan budaya mencipta pekerjaan sendiri dapat dipupuk, sehingga penggangguran boleh dicegah. Isu pengangguran dalam kalangan alumni pendidikan tingi bukan perkara baru dan selalu menjadi masalah kepada negara. Masalah pengangguran berlaku setiap kali universiti mengeluarkan beribu-ribu alumni setiap tahun. Kemahiran dan pengetahuan yang dimiliki oleh para alumni tidak dapat digunakan untuk menyumbang kepada pembangunan negara (Mohd.Hasan, 2007)

Bambang (2011), menegaskn bahwa alumni institusi perguruan tinggi di Indonesia lebih suka bekerja sebagai pegawai negeri jika dibandingkan dengan bekerja sendiri. Keadaan ini juga berlaku kerana kurangnya dukungan daripada ibu bapa. Kebanyakan ibu bapa 
inginkan kerjaya yang terjamin untuk anak-anak mereka. Bagi mereka, bekerja sebagai pegawai negeri mempunyai risiko yang kecil jika dibandingkan dengan kerjaya sebagai pengusaha. Soalan kurangnya keinginan alumni Institusi Perguruan Tinggi (IPT) mencipta kerja sendiri dan mereka lebih suka bekerja sebagai pegawai negeri, hal ini selari dengan keinginan ibu bapa mereka. Keadaan ini bertolak belakang dengan tujuan pembelajaran Kewirausahaan daripada IPT. Pembelajaran Kewirausahaan mestilah dapat menyokong keinginan dan tekad alumniya menjadi pengusaha. Keadaan ini sangat menarik untuk diselidik.

Setakat ini, pengusaha Indonesia hanya berjumlah $0.2 \%$ daripada keseluruhan jumlah penduduk. Untuk mencapai ekonomi ideal, sepatutnya Indonesia mempunyai minimum $2 \%$ pengusaha daripada jumlah penduduk. Kekurangan penceburan dalam bidang Kewirausahaan ini kerana sebahagian besar daripada mereka masih cenderung untuk memilih menjadi buruh atau orang gajian. Perlu disedari bahwa semakin besar jumlah orang terdidik yang tamat IPT, maka semakin besar pula potensi jumlah pengangguran.

Rendahnya keinginan alumni pendidikan tinggi untuk membuka usaha sendiri tidak lepas daripada kesalahan yang terjadi di sekolah. Keadaan yang berlaku di sekolah formal menjadi salah satu perencat potensi manusia sejak lahir. Yang lebih menyedihkan adalah bahwa pendidikan formal tidak hanya mempunyai kuasa untuk menghalang bakal pengusaha tetapi mempunyai kuasa untuk memusnah atau melumpuhkan potensi pengusaha mahasiswanya. Sepatutnya pendidikan formal boleh membangunkan dan melatih bakal pengusaha (Feri Yang,
2008)

Bagaimanakah memberikan motivasi kepada mahasiswa supaya mahu dan berhasrat untuk menjadi pengusaha dan mempunyai keberanian membuka perniagaan sendiri?. Menjawab soalan ini perlu disiasat, apakah faktor-faktor yang mempengaruhi tekad Kewirausahaan alumni daripada institusi perguruan tinggi.

\section{METODE PENELITIAN}

Populasi bagi penelitian ini ialah mahasiswa Universiti di Pekanbaru Riau, ianya selari dengan tujuan penelitian. Jumlah keseluruhan mahasiswa universiti di Pekanbaru adalah seramai 61407 orang (Badan Statitistik Kota Pekanbaru 2012).

Pengambilan sampel mengikut nisbah tahap kesilapan 0.05 dan tahap keyakinan $95 \%$, sehingga jumlah sampel adalah 400 orang yang dikumpulkan menggunakan

teknik pensampelan multi-stage sampling (penarikan sampel banyak tahap).

\section{HASIL DAN PEMBAHASAN}

Guna menjawab soalan penelitian kesatu, kedua dan ketiga dilakukan analisis jalur kelompok semua sampel. Model analisis semua sampel diperuntukkan bagi menjawab soalan penelitian kesatu serta menguji hipotesis satu (H1), hipotesis dua $(\mathrm{H} 2)$ dan hipotesis tiga $(\mathrm{H} 3)$, iaitu melihat pengaruh variabel Akses Modal, Jaringan Sosial, Pengetahuan Kewirausahaan, Motivasi Berprestasi dan Efikasi Diri Terhadap Tekad Kewirausahaan mahasiswa Perguruan Tinggi di Provinsi Riau. Hasil analisis jalur dipertonton seperti Gambar 4.1 berikut. 


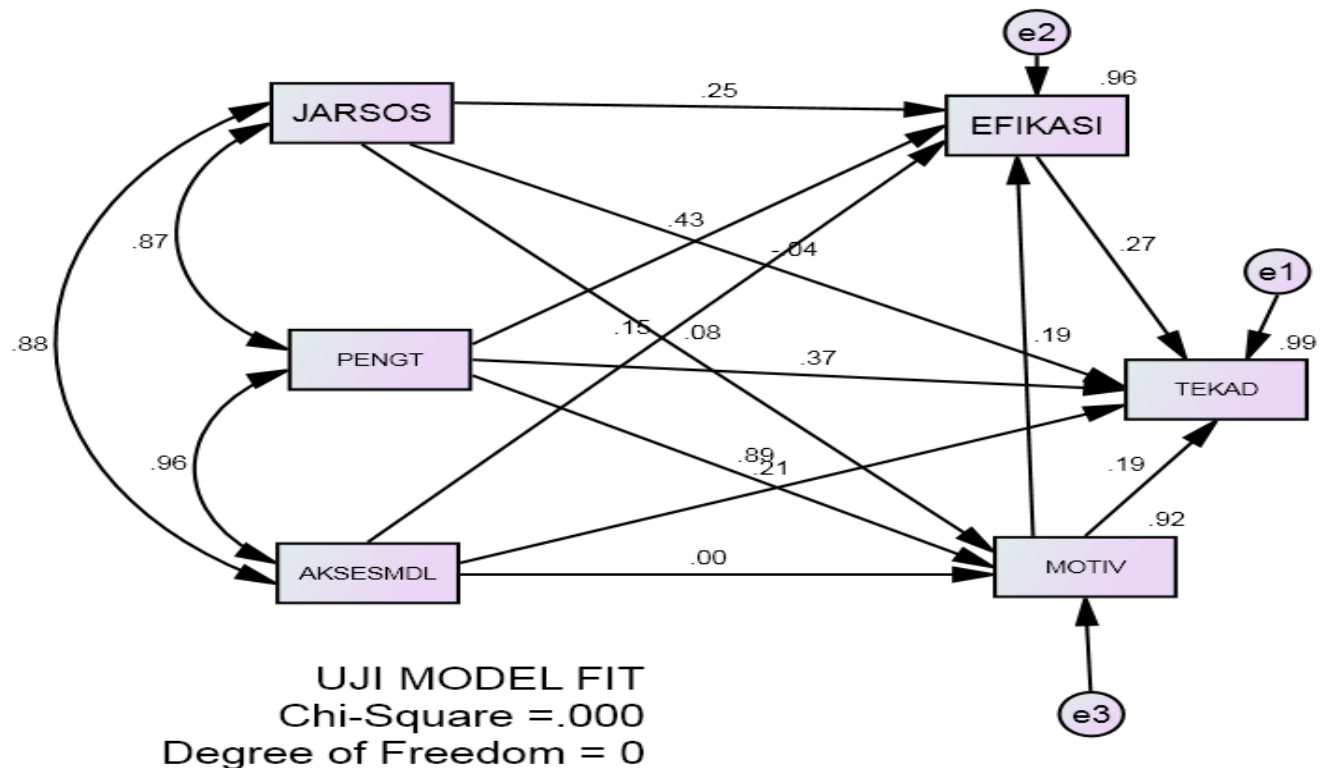

Gambar 1. Analisis Jalur Semua Sampel (jumlah sampel = 389=389)

Gambar 1 memperlihatkan hasil ujian analisis jalur menggunakan AMOS. Dapatan analisis kesepadan model dengan sampel penuh memperlihatkan beberapa kelemahan seperti hasil uji model fit dan koefesien jalur antara akses modal dengan motivasi berprestasi (0.00). Kriteria uji model fit tidak memenuhi persyaratan perlu diperbaiki atau Triming. Triming adalah kaedah biasa diguna pakai para penyelidik untuk memperbaiki model (Haise, 1996 dalam Kusnendi, 2010). Perbaikan dilakukan dengan mengeluarkan kaitan antara akses modal dengan motivasi berprestasi. Hasil perbaikan model diperlihatkan Gambar 4.2.

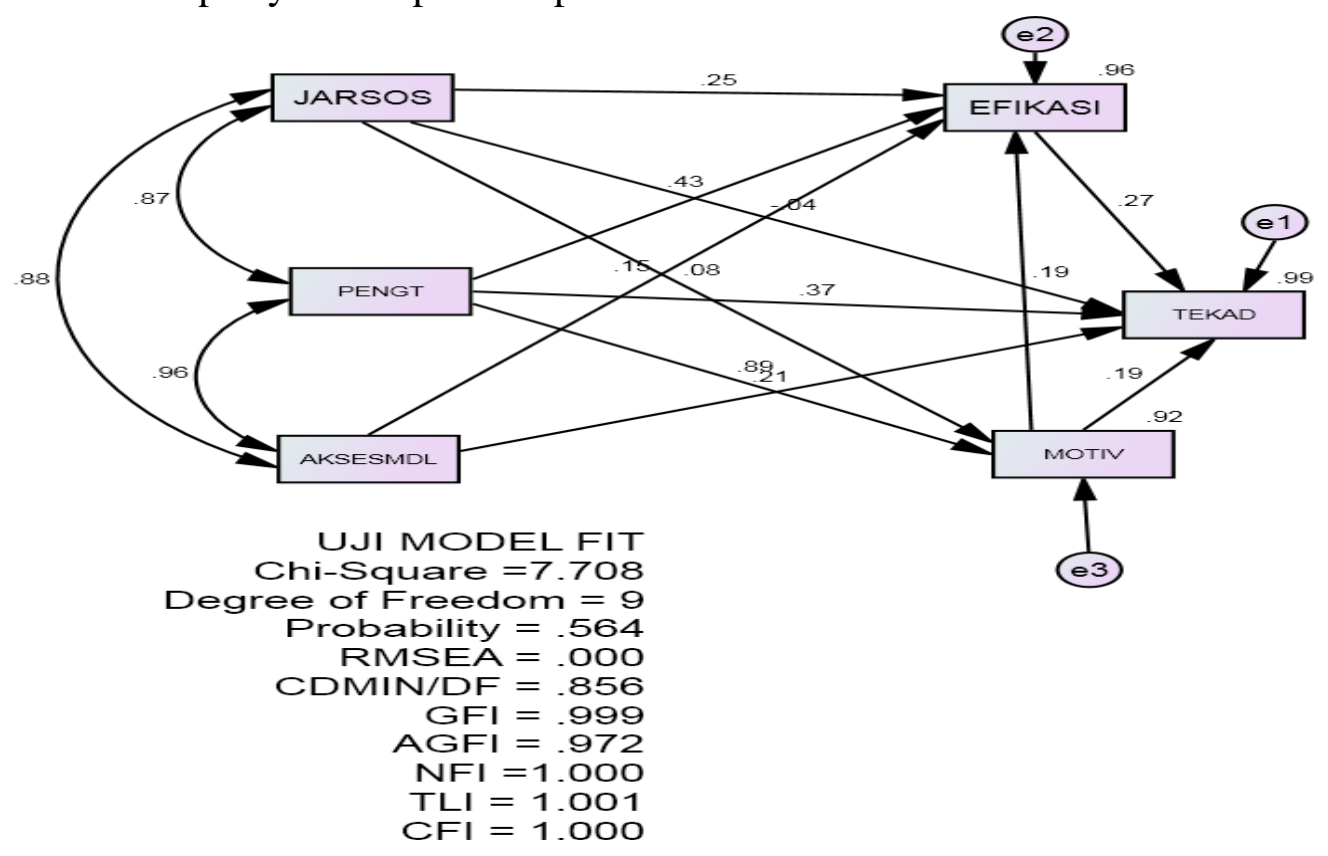

Gambar 2. Triming Model Semua Sampel (Ukuran sampel = 389=389) 
Setelah perbaikan model iaitu dengan menghapus atau mengeluarkan garis panah searah antara akses modal dengan motivasi terlihat hasil ujian model fit cukup baik iaitu , CFI $=1.000$ $\geq 0.90$ berarti model fit, nilai RMSEA perolehan iaitu 0.000 atau RMSEA $\leq$
0.08 Secara keseluruhan model fit dengan data kerana hampir keseluruhan kriteria yang diminta adalah baik.

Ringkasan keputusan analisis ujian kesesuaian model semua sampel dipamerkan melalui tabel berikut ini.

Tabel 2.1:Ujian Kriteria Kesesuaian Model

\begin{tabular}{llll}
\hline Goodneess of fit index & Perolehan & Cut-off value & Hasil \\
\hline$\chi^{2}-$ Chi Square & 7.708 & Diharapkan kecil & Baik \\
\hline Significance Probability & 0.564 & $\geq 0.05$ & Baik \\
\hline RMSEA & 0.000 & $\leq 0.08$ & Baik \\
\hline GFI & 0.999 & $\geq 0.90$ & Baik \\
\hline AGFI & 0.972 & $\geq 0.90$ & Baik \\
\hline CMIN/ DF & 0.856 & $\leq 2.00$ & Baik \\
\hline TLI & 1.001 & $\geq 0.95$ & Baik \\
\hline CFI & 1.000 & $\geq 0.95$ & Baik \\
\hline
\end{tabular}

Tabel 1 memperlihatkan keputusan analisis ujian kesesuaian model, daripada 8 (delapan) kriteria yang ditetapkan dalam analysis jalur, kesemuanya baik sehingga model sesuai dengan data.
Keputusan analisis kesepadan data dengan model dipertontonkantabel 4.9. Nilai Critical Ratio (CR) dalam Regression Weight yang berada di luar lingkungan \pm 1.96 dianggap signifikan pada aras $\mathrm{p}>0.5$.

Tabel 2.2: Ujian Kesepadanan Data dengan Model

\begin{tabular}{lllrrrrl}
\hline & & Estimate & S.E. & C.R. & P & Label \\
\hline MOTIV & $<---$ & JARSOS & .213 & .083 & 2.564 & .010 & b9_1 \\
\hline MOTIV & $<---$ & PENGT & 1.139 & .038 & 30.026 & $* * *$ & b3_1 \\
\hline EFIKASI & $<---$ & JARSOS & .843 & .071 & 11.866 & $* * *$ & b1_1 \\
\hline EFIKASI & $<---$ & PENGT & .665 & .074 & 8.948 & $* * *$ & b2_1 \\
\hline EFIKASI & $<---$ & AKSESMDL & .533 & .133 & 4.004 & $* * *$ & b10_1 \\
\hline EFIKASI & $<---$ & MOTIV & .231 & .041 & 5.644 & $* * *$ & \\
\hline TEKAD & $<---$ & EFIKASI & .236 & .025 & 9.550 & $* * *$ & b5_1 \\
\hline TEKAD & $<---$ & MOTIV & .202 & .021 & 9.772 & $* * *$ & b6_1 \\
\hline TEKAD & $<---$ & AKSESMDL & .630 & .066 & 9.549 & $* * *$ & b8_1 \\
\hline TEKAD & $<---$ & PENGT & .508 & .040 & 12.827 & $* * *$ & b11_1 \\
\hline TEKAD & $<---$ & JARSOS & -.108 & .040 & -2.691 & .007 & \\
\hline
\end{tabular}

Tabel 2.2 memperlihatkan keputusan analisis ujian kesepadan data dengan model, menunjukkan bahwa nilai $\mathrm{CR}$ bagi regresi antara variabel keseluruhannya berada di luar lingkungan \pm 1.96 dianggap signifikan pada aras $\mathrm{p}>0.5$. Keputusan ini menunjukkan bahwa model pengukuran yang dibentuk oleh variabel pendam dan variabel penunjuk sepadan (fit) dengan data penelitian. Keputusan ini mengesahkan bahwa variabel pendam bagi model pengukurannya dalam persamaan struktur tersebut secara 
signifikan dapat dipercayai.

Analisis jalur juga menghasilkan keputusan tentang pengaruh langsung (direct effects) dan pengaruh tidak langsung (indirect effects) serta pengaruh keseluruhan (total effects) diantara variabel. Hasil analisis yang diguna pakai tentang pengaruh pelbagai variabel ialah analisis yang sudah di standarkan (standardized). Rumusan keputusan analisis pengaruh langsung serta pengaruh tidak langsung antara pelbagai variabel penelitian ini dipertontonkan melaluitabel 4.10.. Keputusan analisis jalur tentang variabel yang mempengaruhi tekad Kewirausahaan mahasiswa diringkas sepertitabel 2.3.

Tabel 2.3: Variabel Mempengaruhi Tekad Kewirausahaan Model Semua Sampel.

\begin{tabular}{llcl}
\hline \multirow{2}{*}{ Variabel } & \multicolumn{3}{c}{ Tekad Kewirausahaan } \\
\cline { 2 - 4 } & \multicolumn{3}{c}{ Dipengaruhi } \\
\hline & .209 & Tidak Langsung & Jumlah \\
\hline Akses Modal & -.036 & .042 & .251 \\
\hline Jaringan Sosial & .374 & .085 & .049 \\
\hline Pengetahuan pengusaha & .190 & .330 & .704 \\
\hline Motivasi Berprestasi. & .271 & .051 & .241 \\
\hline Efikasi Diri & & - & .271 \\
\hline
\end{tabular}

Keputusan analisistabel $\quad 4.10$ menunjukkan bahwa tekad Kewirausahaan mahasiswa di pengaruhi secara langsung oleh akses modal (0.209), jaringan sosial (-0.036) pengetahuan Kewirausahaan (0.374), motivasi berprestasi (0.190) dan efikasi diri (0.271). Manakala hal yang mempengaruhi secara tidak langsung iaitu akses modal (0.042), jaringan sosial (0.085), pengetahuan Kewirausahaan (0.330) dan motivasi berprestasi (0.051) sedangkan efikasi diri tidak mempengaruhi secara tidak langsung.

Hasil analisistabel 2.3 adalah untuk menjawab soalan penelitian kesatu iaitu bagaimanakah wujud pengaruh
Tabel 2.4: Variabel Mempengaruhi Efikasi

\begin{tabular}{|c|c|c|c|}
\hline \multirow{3}{*}{ Variabel } & \multicolumn{3}{|c|}{ Efikasi Diri } \\
\hline & \multicolumn{3}{|c|}{ Dipengaruhi } \\
\hline & Langsung & Tidak Langsung & Jumlah \\
\hline Akses Modal & .154 & - & .154 \\
\hline Jaringan Sosial & .247 & .014 & .261 \\
\hline Pengetahuan Pengusaha & .425 & .169 & .594 \\
\hline Motivasi Berprestasi. & .189 & - & .189 \\
\hline
\end{tabular}

$\begin{array}{lll}\text { Keputusan } & \text { analisistabel menunjukkan bahwa efikasi diri }\end{array}$ 
dipengaruhi secara langsung oleh akses modal (0.154), jaringan sosial (0.247), pengetahuan Kewirausahaan (0.425), motivasi berprestasi (0.189). Manakala pengaruh tidak langsung terhadap efikasi diri iaitu jaringan social (0.014) dan pengetahuan pengusaha $(0.169)$.

Keputusan analisistabel 2.4 menjawab soalan penelitian kedua iaitu apakah terdapat pengaruh akses modal, pengetahuan Kewirausahaan, jaringan sosial dan motivasi berprestasi terhadap efikasi diri mahasiswa institusi pendidikan tinggi di Provinsi Riau. Dapatan penelitian menjelaskan bahwa efikasi diri dipengaruhi akses modal, pengetahuan keusawanan, jaringan sosial dan motivasi berprestasi.

Seterusnya untuk menjawab soalan penelitian ketiga diperlihatkan melalui keputusan analisis jalur tentang variabel yang mempengaruhi motivasi berprestasi mahasiswa diringkas sepertitabel 2.5.

Tabel 2.5: Variabel Mempengaruhi Motivasi Berprestasi Model Semua Sampel

\begin{tabular}{|c|c|c|c|}
\hline \multirow[t]{3}{*}{ Variabel } & \multicolumn{3}{|c|}{ Motivasi Berprestasi } \\
\hline & & Dipengaruhi & \\
\hline & Langsung & Tidak Langsung & Jumlah \\
\hline Jaringan Sosial & .076 & - & .076 \\
\hline Pengetahuan pengusaha & .891 & - & .891 \\
\hline
\end{tabular}

Tabel 2.5 mempamerkan bahwa motivasi berprestasi dipengaruhi secara langsung oleh jaringan sosial (0.076) dan pengetahuan pengusaha (0.891). Tidak ada pangaruh tidak langsung daripada masing masing variabel.

Hasil analisis tabel 2.5 adalah untuk menjawab soalan penelitian ketiga iaitu bagaimanakah wujud pengaruh akses modal, pengetahuan Kewirausahaan, jaringan sosial dan efikasi diri terhadap motivasi berprestasi mahasiswa institusi pendidikan tinggi di Provinsi Riau. Dapatan analisis memperlihatkan bahwa motivasi berprestasi dipengaruhi oleh jaringan sosial dan pengetahuan Kewirausahaan, sedangkan akses modal, dan efikasi diri tidak berpengaruh terhadap motivasi berprestasi.

Seterusnya untuk memperjelas perbandingan koefisen yang mempengaruhi tekad Kewirausahaan daripada kedua-dua kelompok sampel lelaki dengan kelompok sampel perempuan digambar dalam gambar berikut ini.

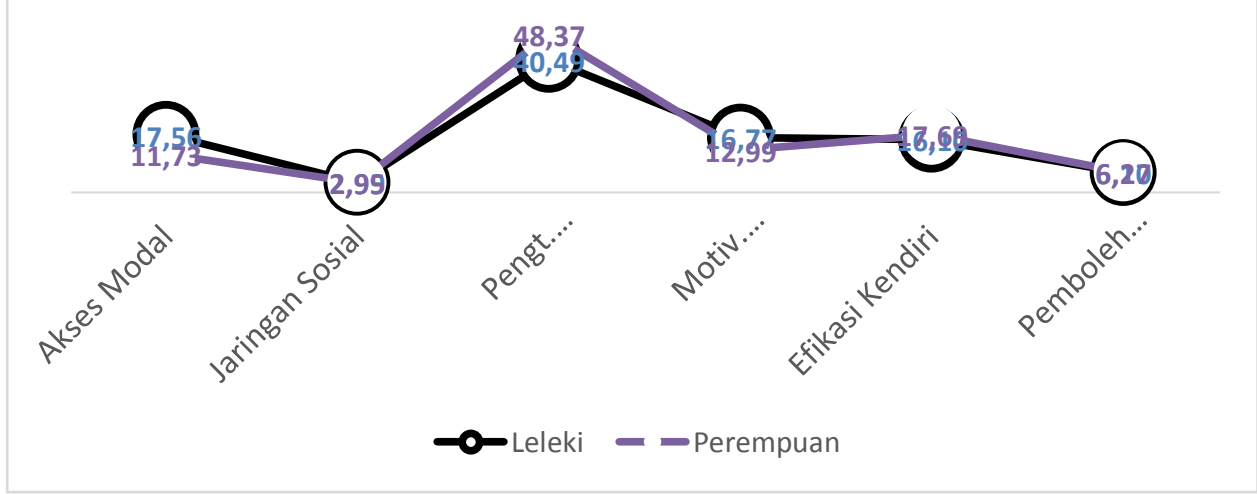

Gambar 2.3 Perbandingan koefisen tekad Kewirausahaan laki-laki dan perempuan.

Gambar 2.3 memperlihatkan perbandingan koefisen yang 
mempengaruhi tekad Kewirausahaan mahasiswa lelaki dengan mahasiswa perempuan. Hasil analisis memperlihatkan bahwa akses modal, jaringan sosial, pengetahuan Kewirausahaan dan motivasi berprestasi serta efikasi diri berbanding lurus antara kedua kelompok sampel. Manakala dikaitkan dengan hipotesis yang dikemukakan iaitu: Jenis kelamin memoderasi pengaruh terhadap tekad Kewirausahaan mahasiswa institusi pendidikan tinggi di Provinsi Riau, hipotesis di tolak. Hal ini berarti bahwa jenis kelamin tidak memoderasi tekad Kewirausahaan mahasiswa institusi pendidikan tinggi di Provinsi Riau.

Seterusnya untuk memperjelas perbandingan koefesien yang mempengaruhi tekad Kewirausahaan daripada kelompok sampel yang tinggal bersama ibu bapa dengan kelompok sampel yang tinggal di rumah sewa digambar dalam gambar berikut ini.

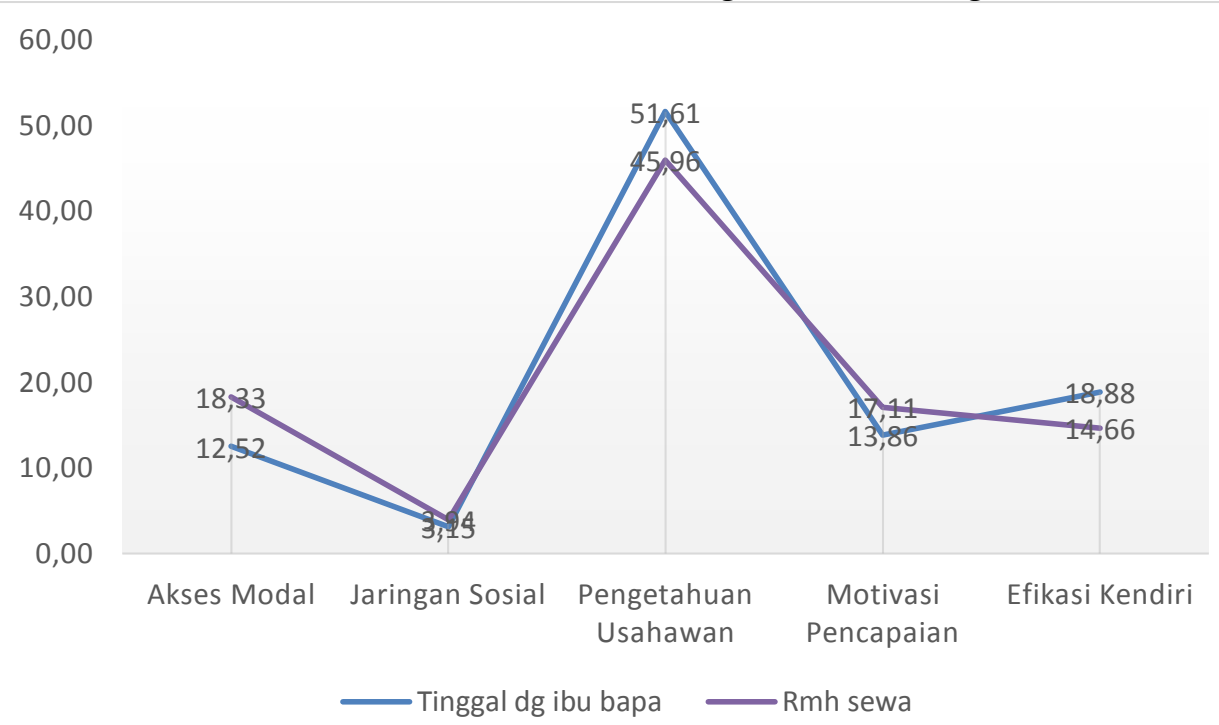

Gambar 2.4 : Perbandingan koefesien yang mempengaruhi Tekad Kewirausahaan Mahasiswa daripada kelompok sampel yang tinggal bersama ibu bapa dengan kelompok sampel yang tinggal di rumah sewa.

Gambar 2.4 memperlihatkan perban dingan koefesien yang mempengaruhi tekad Kewirausahaan mahasiswa yang tinggal bersama ibu bapa dengan mahasiswa yang tinggal di rumah sewa. Gambar 2.4 memperlihatkan bahwa akses modal dan jaringan sosial tidak berbeza tingkat pengaruh, sedangkan pengetahuan Kewirausahaan berban ding lurus antara kedua kelompok sampel. Manakala dikaitkan dengan hipotesis yang dikemukakan iaitu: Tempat tinggal semasa kuliah memoderasi pengaruh terhadap tekad Kewirausahaan mahasiswa institusi pendidikan tinggi di Provinsi Riau, hipotesis di tolak. Hal ini berarti bahwa tempat tinggal tidak memoderasi tekad Kewirausahaan mahasiswa institusi pendidikan tinggi di Provinsi Riau.

Seterusnya untuk memperjelas perbandingan koefesien yang mempengaruhi tekad Kewirausahaan mahasiswa dari kelompok sampel dukungan keuangan sendiri dengan kelompok sampel dengan dukungan keuangan daripada ibu bapa digambar dalam gambar berikut ini. 


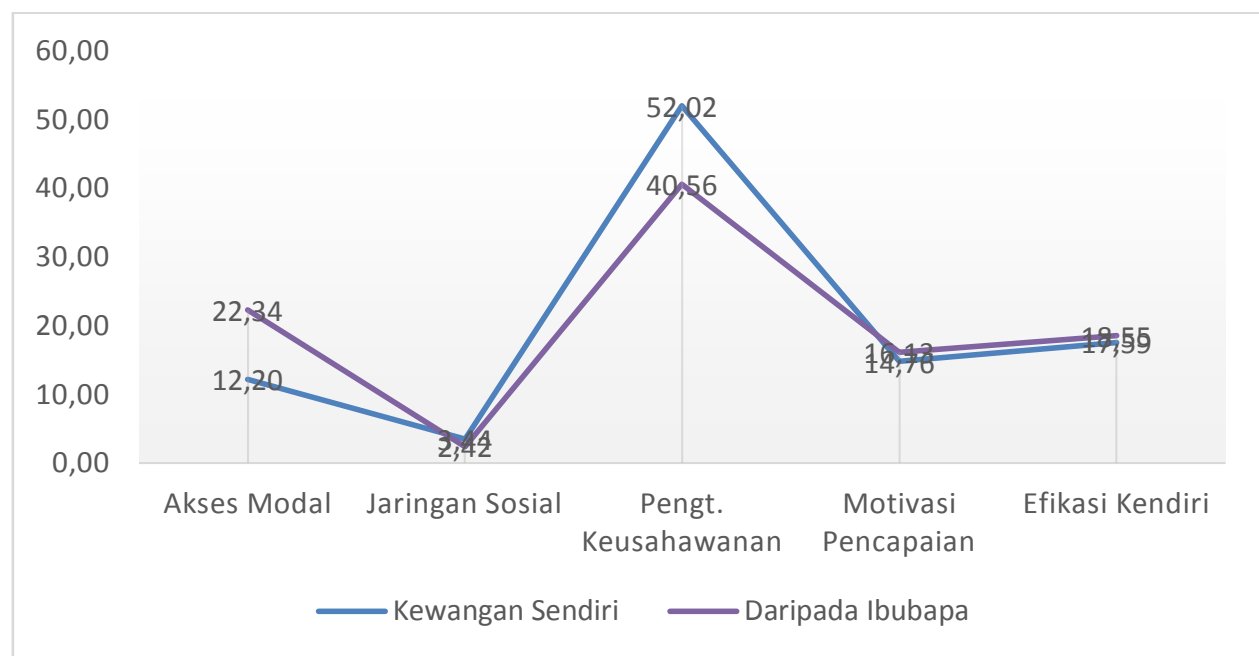

Gambar 2.5 : Perbandingan koefesien yang mempengaruhi Tekad Kewirausahaan Mahasiswa daripada kelompok sampel dukungan keuangan sendiri dengan kelompok sampel dengan dukungan keuangan daripada ibu bapa.

Gambar $\quad 2.5 \quad$ memperlihatkan perbandingan koefesien yang mempengaruhi tekad Kewirausahaan mahasiswa dengan dukungan keuangan sendiri dengan mahasiswa dengan dukungan keuangan daripada ibu bapa. Gambar 2.5 memperlihatkan bahwa tidak terdapat perberbezaan tingkat pengaruh masing masing variabel terhadap tekad Kewirausahaan mahasiswa dengan dukungan keuangan sendiri dengan mahasiswa dengan dukungan keuangan daripada ibubapa. Manakala dikaitkan dengan hipotesis yang dikemukakan iaitu: Dukungan keuangan semasa kuliah memoderasi pengaruh terhadap tekad
Kewirausahaan mahasiswa institusi pendidikan tinggi di Provinsi Riau, hipotesis di tolak. Hal ini berarti bahwa dukungan keuangan mahasiswa tidak memoderasi tekad Kewirausahaan mahasiswa institusi pendidikan tinggi di Provinsi Riau.

Seterusnya untuk memperjelas perbandingan koefesien yang mempengaruhi tekad Kewirausahaan mahasiswa antara kelompok sampel yang aktif ikut organisasi dengan kelompok sampel yang tidak ikut organisasi digambar dalam gambar 2.6 berikut ini.

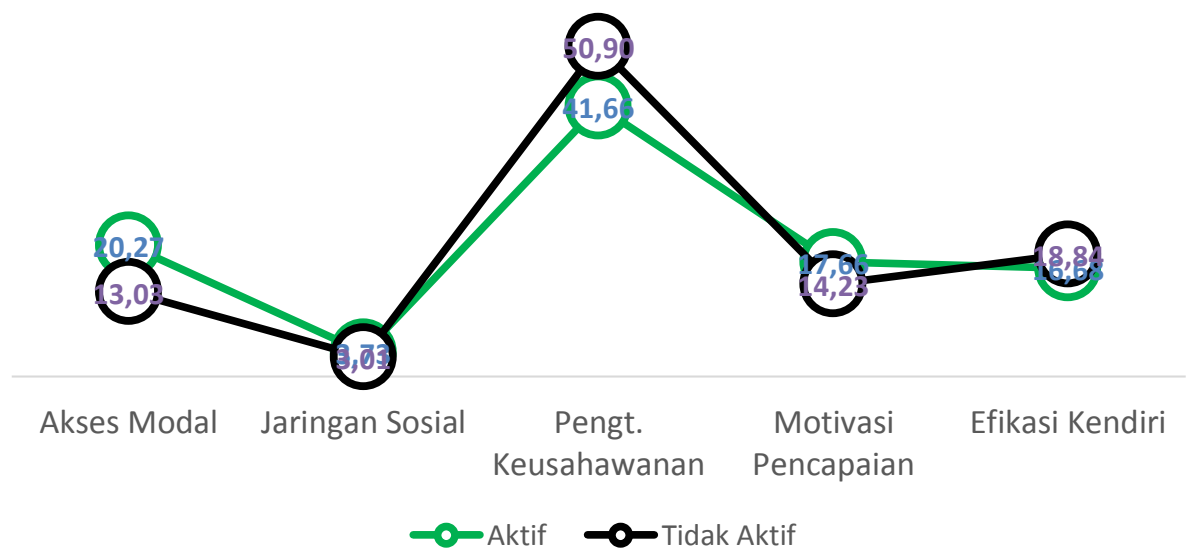

Gambar 2.6 : Perbandingan koefesien yang mempengaruhi tekad Kewirausahaan mahasiswa antara kelompok sampel yang aktif ikut organisasi dengan kelompok sampel yang tidak ikut organisasi 
Gambar 2.6 memperlihatkan perbandingan koefesien yang mempengaruhi tekad Kewirausahaan mahasiswa yang aktif ikut organisasi dengan mahasiswa dengan mahasiswa yang tidak ikut organisasi Gambar 2.6 memperlihatkan bahwa tidak terdapat perberbedaan tingkat pengaruh dari masing masing pemboleh daripada kedua sampel tersebut. Manakala dikaitkan dengan hipotesis yang dikemukakan iaitu: aktifitas organisasi memoderasi pengaruh terhadap tekad Kewirausahaan mahasiswa institusi pendidikan tinggi di Provinsi Riau, hipotesis di tolak. Hal ini berarti bahwa keterlibatan dalam organisasi tidak memoderasi tekad Kewirausahaan mahasiswa institusi pendidikan tinggi di Provinsi Riau.

\section{PEMBAHASAN}

\section{Keadaan Diri Terhadap Tekad Kewirausahaan}

Beberapa perkara sudah dibincangkan dan dapatan penelitian ini memperlihatkan efikasi diri merupakan unsur penentu utama dalam mewujudkan tekad Kewirausahaan seseorang. Mahasiswa yang memiliki kepercayaan diri yang tinggi cenderung memiliki tekad atau kemahuan Kewirausahaan. Persamaan struktural daripada olahan SEM menunjukkan bahwa $71 \%$ tekad Kewirausahaan dipengaruhi oleh efikasi diri. Dapatan penelitian ini selari dengan pendapat Betz dan Hacket dalam Indarti (2010) menyatakan bahwa semakin tinggi tingkat efikasi diri seseorang semakin tinggi pula minatnya terhadap Kewirausahaan. Selain itu, Gilles dan Rea dalam Indarti (2010)) membuktikan pentingnya efikasi diri dalam proses pengambilan keputusan berkaitan dengan kerjaya seseorang. Efikasi diri terbukti signifikan menjadi penentu tekad seseorang. Efikasi diri terbukti mempengaruhi tekad Kewirausahaan mahasiswa Indonesia dan Norway. Semakin tinggi kepercayaan diri seorang mahasiswa atas kemampuan dirinya untuk dapat berusaha, maka semakin besar pula keinginannya untuk menjadi seorang pengusaha (Cromie, 2000). Manakala, responden mahasiswa Jepang tidak berpengaruh efikasi diri terhadap keinginan menjadi pengusaha (Indarti 2010).

\section{Unsur Penyokong dengan Tekad Kewirausahaan}

Dapatan ini memperlihatkan

bahwa akses modal tidak terlalu signifikan mempengaruhi tekad Kewirausahaan. Temuan ini kurang sefaham dengan penjelasan Indarti (2004) dan Kristiansen (2003), yang menyatakan bahwa akses kepada modal adalah halangan klasik, terutama dalam perniagaan baru, sekurang-kurangnya berlaku di negara-negara membangun dengan dukungan lembaga penyedia keuangan dan institusi-institusi yang tidak sangat kuat dan akses kepada modal untuk menjadi salah satu penentu suksesnya usaha. Tekad Kewirausahaan mahasiswa hampir tidak terpengaruh oleh ketersediaan modal .

Unsur penyokong lainnya iaitu pengetahuan Kewirausahaan yang dimiliki seseorang. Apabila seseorang memahami tentang Kewirausahaan mestinya dia akan mempunyai tekad yang lebih kuat daripada seseorang yang tidak memiliki pengetahuan Kewirausahaan. Sinha dalam Indarti (2010) mengemukkan bahwa latar belakang pendidikan seseorang terutama yang terkait dengan bidang pengusaha, dipercaya akan mempengaruhi keinginan dan minatnya untuk memulai usaha baru di masa mendatang. Sebuah studi dari India membuktikan bahwa latar belakang pendidikan menjadi salah satu penentu penting tekad Kewirausahaan dan kejayaan usaha yang dijalankan.

\section{Faktor Demografi dengan Tekad Kewirausahaan}

Dapatan penelitian ini selari dengan dapatan Norasmah (2007) bahwa tidak 
terdapat perbezaan yang ketara antara remaja lelaki dengan remaja perempuan tentang tingkah laku nonkognitif Kewirausahaan. Berbeza dengan beberapa penelitian lepas, bahwa mahasiswa laki-laki mempunyai komitmen yang kuat daripada mahasiswa perempuan. Secara umum, sektor pengusaha banyak di kuasai oleh kaum laki-laki. Mazzarol (1999) menunjukkan bahwa wanita cenderung untuk tidak membuka usaha baru berbading kaum laki-laki. Temuan serupa juga dibentangkan oleh Kolvereid (1996), laki-laki terbukti mempunyai tekad pengusaha yang lebih tinggi berbanding perempuan.

Dalam konteks penelitian ini, tempat tinggal semasa kuliah tidak memoderasi tekad Kewirausahaan mahasiswa institusi pendidikan tinggi di Provinsi Riau. Tidak terdapat perbedaan tekad Kewirausahaan antara mahasiswa yang tinggal bersama ibu bapa dengan mahasiswa yang tinggal di rumah sewa.
Apabila dilihat daripada unsur yang mempengaruhi, mahasiswa yang tinggal bersama ibu bapa, unsur dominan yang mempengaruhi tekad kepengusahanya ialah pengetahuan Kewirausahaan, manakala mahasiswa yang berkediaman di rumah sewa, dominan yang mempengaruhi tekad Kewirausahaan ialah efikasi diri. Dapatan penelitian ini tidak selari dengan penelitian lepas Linan (2007), bahwa dalam menentukan hala tuju kerjaya seseorang itu, faktor persekitaran yang merangkumi nilai pendekatan dan nilai sosial didapati mempunyai pengaruh yang kuat dalam keputusan yang di buat oleh mahasiswa.

\section{Implikasi}

Huraian diatas dapat diambil kesimpulan tentang unsur yang berpengaruh terhadap tekad Kewirausahaan baik berpengaruh secara langsung mahupun yang berpengaruh secara tidak langsung, seperti dalam gambar berikut.

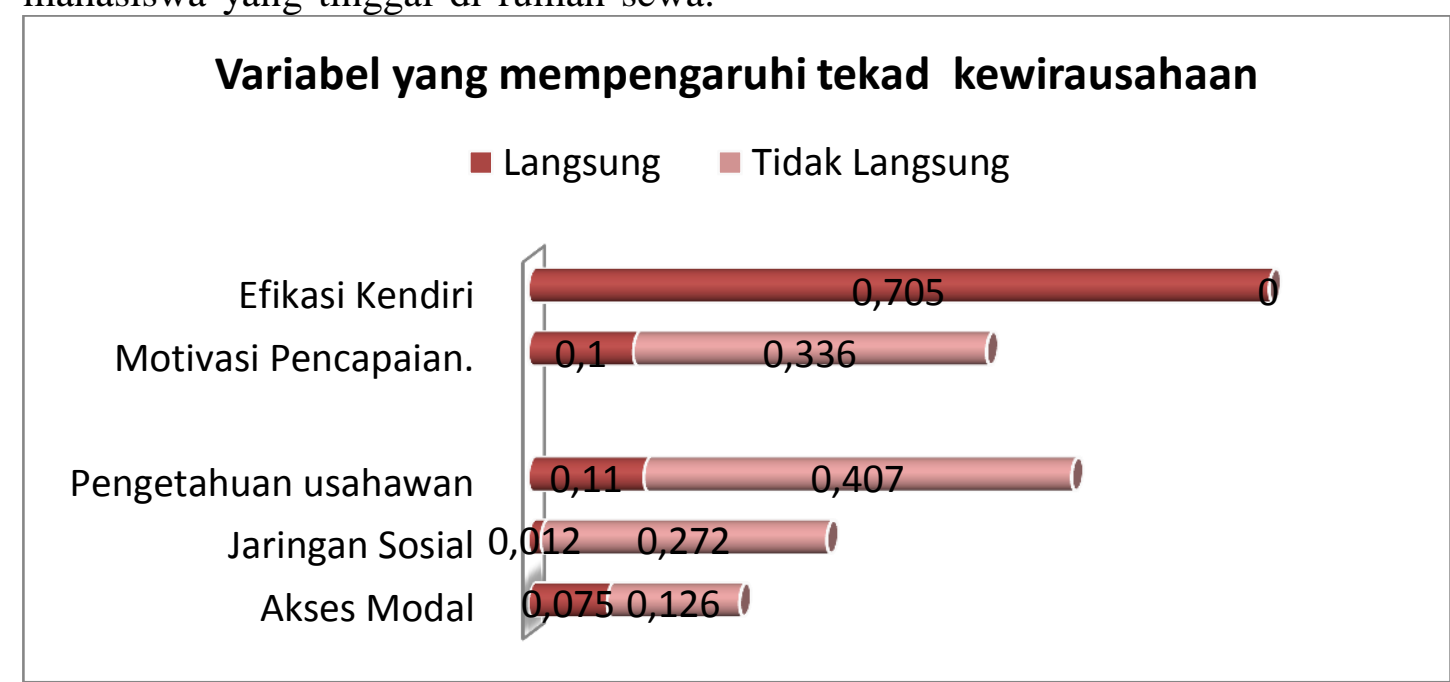

Gambar 2.7: Faktor yang mempengaruhi tekad Kewirausahaan mahasiswa Institusi Perguruan Tinggi di Pekanbaru. 
Menjadi pengusaha bagi kalangan mahasiswa institusi perguruan tinggi ternyata yang paling diperlukan ialah efikasi diri, sehingga dalam pembelajaran Kewirausahaan pada institusi perguruan tinggi kurikulumnya mestilah mendalami tentang membang kitkan efikasi diri didalam diri mahasiswa. Efikasi diri terkait dengan pengetahuan Kewirausahaan dan motivasi berprestasi. Manakala motivasi berprestasi dipengaruhi oleh jaringan sosial dan pengetahuan Kewirausahaan.

Penjelasan ini bermakna bahwa seseorang mahasiswa akan mempunyai tekad Kewirausahaan apabila dalam dirinya ada efikasi diri yang kuat. Efikasi diri ini perlu disokong oleh pengetahuan Kewirausahaan dan motivasi berprestasi. Artinya kurikulum Kewirausahaan pada institusi perguruan tinggi mestilah mengaitkan dengan efikasi diri dan motivasi berprestasi.

Berdasarkan gambaran di atas dapat disenaraikan isi kurikulum Kewirausa haan pada institusi perguruan tinggi sebagai berikut:

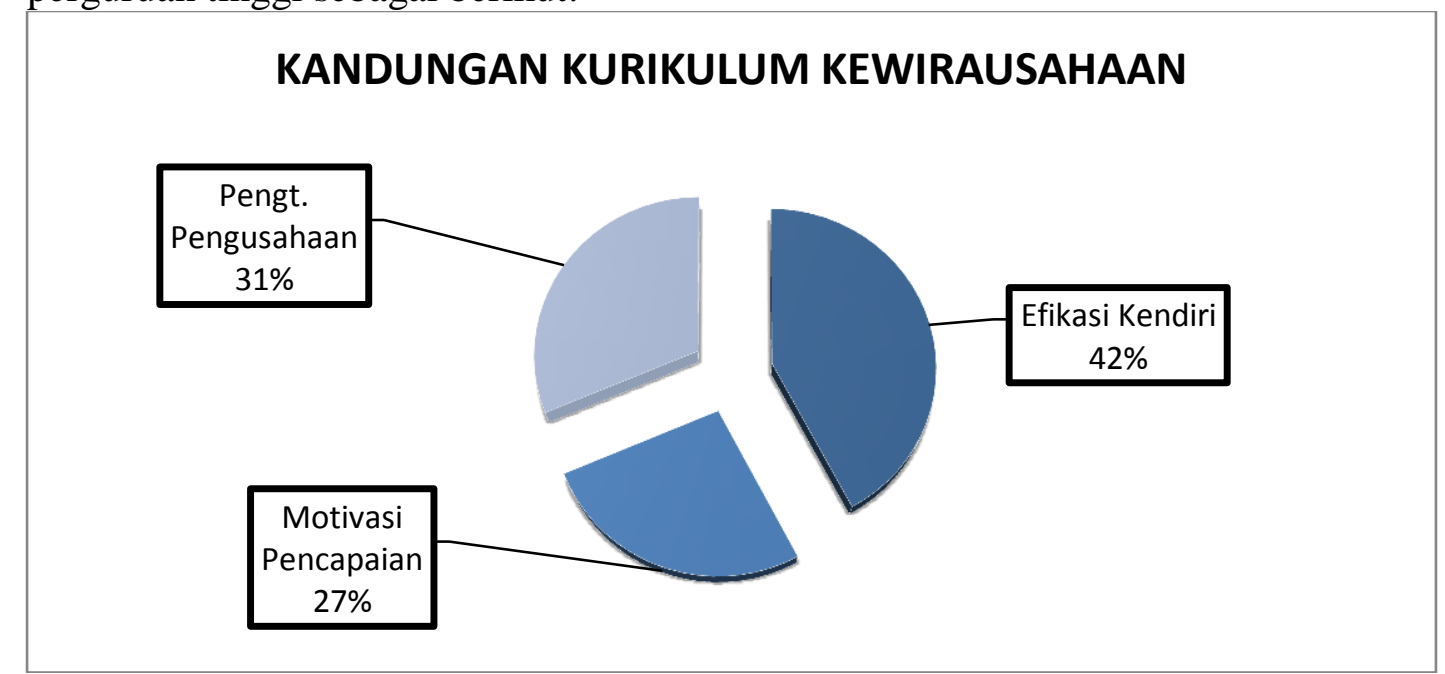

Gambar 2.8: Kandungan Mahasiswaan Kewirausahaan

Kandungan mahasiswaan efikasi diri lebih banyak menyajikan tentang penanaman rasa percaya diri yang tinggi ( bahan penelitian psikologi). Manakala tentang motivasi berprestasi berisikan tentang memberikan dorongan agar mahasiswa menjadi seorang yang berani menghadapi risiko dan cabaran. Pengetahuan Kewirausahaan pula berisikan pengetahuan memulai, menjalankan dan mengembangkan usaha.

Melalui kepentingan dan implikasi penelitian yang telah dibincangkan di atas, peneliti mengharapkan agar pihak universiti dapat menjadikannya sebagai panduan untuk membangunkan pengusaha di Institusi Perguruan Tinggi di Provinsi Riau. Ini selaras dengan himbauan pemerintah yang inginkan lebih banyak lagi alumni menjadi pengusaha untuk meningkatkan taraf ekonomi negara.

\section{Kesimpulan}

Berdasar analisis data pada bahagian sebelumnya, dapat dirumuskan hasil penelitian ini, iaitu :

1) Terdapat pengaruh yang signifikan antara akses modal, jaringan sosial, pengetahuan pengusahaan dan motivasi berprestasi terhadap tekad Kewirausahaan mahasiswa Institusi Perguruan Tinggi di Provinsi Riau

2) Terdapat pengaruh akses modal, jaringan sosial, pengetahuan pengusahaan dan motivasi berprestasi terhadap efikasi diri mahasiswa Institusi Perguruan Tinggi di Provinsi Riau

3) Terdapat pengaruh akses modal, jaringan sosial, pengetahuan pengusahaan dan efikasi diri terhadap motivasi berprestasi mahasiswa Institusi Perguruan Tinggi di Provinsi 
Riau

4) Jenis kelamin memoderasi akses modal, jaringan sosial, pengetahuan pengusahaan, motivasi berprestasi dan efikasi diri terhadap tekad Kewirausahaan mahasiswa Institusi Perguruan Tinggi di Provinsi Riau

5) Jenis kelamin memoderasi akses modal, jaringan sosial, pengetahuan pengusahaan dan motivasi berprestasi terhadap efikasi diri mahasiswa Institusi Perguruan Tinggi di Provinsi Riau

6) Jenis kelamin tidak memoderasi akses modal, jaringan sosial, pengetahuan pengusahaan dan efikasi diri terhadap motivasi berprestasi mahasiswa Institusi Perguruan Tinggi di Provinsi Riau

7) Tempat kediaman semasa kuliah tidak memoderasi akses modal, jaringan sosial, pengetahuan pengusahaan, motivasi berprestasi dan efikasi diri terhadap tekad Kewirausahaan mahasiswa Institusi Perguruan Tinggi di Provinsi Riau

8) Tempat tinggal semasa kuliah memoderasi akses modal, jaringan sosial, pengetahuan pengusahaan dan motivasi berprestasi terhadap efikasi diri mahasiswa Institusi Perguruan Tinggi di Provinsi Riau

9) Tempat tinggal semasa kuliah tidak memoderasi akses modal, jaringan sosial, pengetahuan pengusahaan dan efikasi diri terhadap motivasi berprestasi mahasiswa Institusi Perguruan Tinggi di Provinsi Riau

10) Dukungan keuangan semasa kuliah tidak memoderasi akses modal, jaringan sosial, pengetahuan pengusahaan, efikasi diri dan motivasi berprestasi terhadap tekad Kewirausahaan mahasiswa Institusi Perguruan Tinggi di Provinsi Riau.

11) Dukungan keuangan semasa kuliah tidak memoderasi akses modal, jaringan sosial, pengetahuan pengusahaan dan motivasi berprestasi terhadap efikasi diri mahasiswa
Institusi Perguruan Tinggi di Provinsi Riau

12) Dukungan keuangan semasa kuliah tidak memoderasi akses modal, jaringan sosial, pengetahuan pengusahaan dan efikasi diri terhadap motivasi pencapian mahasiswa Institusi Perguruan Tinggi di Provinsi Riau

13) Aktiviti dalam organisasi tidak memoderasi akses modal. jaringan sosial, pengetahuan pengusahaan, motivasi berprestasi efikasi diri mahasiswa terhadap tekad Kewirausahaan mahasiswa Institusi Perguruan Tinggi di Provinsi Riau.

14) Aktiviti dalam organisasi tidak memoderasi akses modal, jaringan sosial, pengetahuan pengusahaan dan motivasi berprestasi terhadap efikasi diri mahasiswa Institusi Perguruan Tinggi di Provinsi Riau

15) Aktiviti dalam organisasi tidak memoderasi akses modal, jaringan sosial, pengetahuan pengusahaan dan Efikasi diri terhadap Motivasi Berprestasi mahasiswa Institusi Perguruan Tinggi di Provinsi Riau

\section{REFERENSI}

Ab. Aziz Yusof dan Zakaria Yusof, 2004. Prinsip Kewirausahaan Edisi Kedua. Prentice Hall: Pearson Malaysia Sdn.Bhd.

Ab. Aziz Yusof (2003) Prinsip Kewirausahaan, Petaling Jaya:

Pearson Malaysia.

Ab. Aziz Yusof, 2001, Pengusaha Dan Kewirausahaan: Satu Penilaian. Prentice Hall: Pearson Malaysia Sdn.Bhd.

Abu Bakar, 2007, Penglibatan Kaum Wanita Dalam Aktiviti Kewirausahaan di negeri Johor: penelitian terhadap factor-faktor Kritikal Kejayaan dan Kegagalan Pengendalian Perniagaan, Jabatan Pembangunan Sumber Manusia Fakulti Pengurusan dan Pembangunan Sumber Manusia Universiti Teknologi Malaysia 
Afifa, Nindah Nur, 2007, Peran seni dalam mengembangkan kreatifitas siswa. http://media.diknas.go.id/media/docu ment/5465.pdf.

Afia Randa Ritonga (2010), Pengaruh Efikasi Diri, Kesiapan Instrumentasi, dan keinginan akan Prestasi terhadap Minat Mahasiswa Berwirausaha (Studi Kasus Mahasiswa FE UMSU), UMSU, Medan.

Aisyah Hj.Kasa,2009, Pembangunan Instrumen Pengukuran Psikologi Kewirausahaan Belia Malaysia, Universiti Putera Malaysia.

Ajzen, I. 1991. The Theory of Planned Behavior. Organizational Behavior andHuman Decision Processes, 50(2), 179-211).

Ajzen, I. 2002. Perceived Behavioral Control, Self-Efficacy, Locus of Control, and The Theory of Planned Behavior. Journal of Applied Social Psychology, 2(4), 665-683.

Alma Buchari H, 2003, Kewirausahaan, Edisirevisi, Cetakan Kelima, Penebit Alfabeta, Bandung

Al-Rasyid, H.2003 Teknik Penarikan Sampel dan Penyusunan Skala. Pascasarjana UNPAD, Bandung.

Anderson, G. 2002. Fundamentals of Educational Research. Edisi kedua . London: Routledge Farmer.

Angki Adi Tama (2010) Analisis Faktor Faktor Yang Memotivasi Mahasiswa Berkeinginan Menjadi Entrepreneur (Studi pada Mahasiswa SI Fakultas Ekonomi Universitas Diponegoro Semarang)", Skripsi, Undip Semarang

Arikunto, Suharsimi, 2003. Prosedur Penelitian Suatu Pendekatan Praktek,Jakarta: PT. Rineka Cipta

Auken, H. V., Fry, F.L., \& Stephens, P. (2006). The Influence of Role Models on Entrepreneurial Intentions. Journal of Developmental Entrepreneurship, 11 (2), 157-167.

Avin Helmi Fadilla \& Rista Bintara
Megasari, 2007. Modul kuliah Kewirausahaan dari perspektif Psikologi

.(http://www.avin.filsafat.ugm.ac.id, diakses 21 September 2007)

Bambang Dwi Heriantoro, 2007, Pengaruh Profesionalisme, Konflik dan Peran Kepemimpinan Terhadap Produktifitas Pegawai di Jawa Tengah, STIE Mitra Indonesia Yogyakarta.

Basuki, Heru. 2010. Teori-Teori Mengenai Kreativitas. http://v-class.gunadarma. ac.id/ $\underline{\mathrm{mod} / \mathrm{resource} / \mathrm{view} . \mathrm{php} \text { ?id=15524. }}$

Benay Sager, 2006, Implications of a Multi-Disciplinary Educational and Research Environment: Perspectives of Future Business, Law, Science, and Engineering Professionalsin the Technological Innovation: Generating Economic Results(TI:GERw) Program, Technology Analysis \& Strategic Management Vol. 18, No. 1, 57-69, February 2006

Boone E, Louis dan Kurtz L david, 2002, Pengantar Bisnis/Contemprary Business, Alih Bahasa Fadrinsyah Anwar dkk, Jilid I, Penerbit Erlangga, Jakarta.

Badan Pusat Statistik, 2012, http://www.bps.go.id/ tab_sub/view.php? tabel=1 \& daftar $=$ $\underline{1 \& \text { id_subyek }=06 \& \text { notab }=}$ 4http://www. bps. go. id/ etfile. php? News $=849$

Badan Pusat Statistik, 2012, Riau Dalam Angka tahun 2011, BPS Provinsi Riau.

Barjoyai Bardai (2000). "Kewirausahaan dan Perniagaan - Bahagian 1." Kuala Lumpur : Dewan Bahasa dan Pustaka.

Cheng,M.Y. \& Chan, C.2003. Entrepreneurship Education in Malaysia. Cyberjaya: Multymedia University.

Chien, D.J., Liang, T.W. \& Soon, C.T. 1996. Entrepreneurship Inclination of Singapore Business Students. Journal of Enterprising Culture, 4 (2), 209- 
223.

Chi Kim Cheung.2008. Entrepreneurship Education in Hongkong's Secondary Curriculum, Possibilities and limitations, Education+Training 50 $\mathrm{n}(6)$.

Chiew Tung Moi, Tam Yin Ling @ Adelina, Mansur Tola dan Chang Mui Ling @ Dyana, 2011, Asas Keusahaan, Penerbitan Multimedia Sdn. Bhd,.

Christera Kuswahyu Indira, 2010, Students Entrepreneurship Intention: Studi of Comparison Between Java and Non Java ,http://www. gunadarma.ac.id Jurusan Manajemen, fakultas Ekonomi-Universitas Gunadarma

Choo, S., dan M. Wong, 2006. "Entrepreneurial intention: triggers and barriers to new venture creations in Singapore". Singapore Management Review 28 (2): 47-64.

Chua Yan Piaw. 2006. Kaedah Penelitian. Buku I. Kuala Lumpur: Mc. Graw Hill. Creswell, J.W. 2005. Educational Reseach : Planing, conducting and evaluating quantitative and qualitative research. Ed. Kedua. New Jersey:mPearsong Educatinal International.

Crow, L.D. dan Crow, A. 1993.Psikologi Pendidikan Untuk Perguruan. Kuala Lumpur: Dewan Bahasa dan Pustaka.

Dana, L. 2001. The Education Training of Entrepreneurship in Asia, Education \& Training. 43 (8/9):4005-416.

David Rae, 2006, Entrepreneurial Learning: A Conceptual Framework for Technology based Enterprise, Technology Analysis \& Strategic Management, Vol. 18, No. 1, 39-56, February 2006, The Derbyshire Business School, University of Derby, UK

Dhyah Setyorini, 2010, Pengembangan Motivasi Berwirausaha Penyuluhan Kewirausahaan di Dusun Surobayan, Desa Sumber Rejo, Kecamatan Semin, Kabupaten Gunung Kidul, Disajikan pada tanggal 14 Juni 2010

Dian Ratna Sawitri, 2009, Pengaruh Status
Identitas Dan Efikasi Diri Keputusan Karir Terhadap Keraguan Mengambil Keputusan Karir Pada Mahasiswa Tahun Pertama Di Universitas Diponegoro, Fakultas Psikologi UNDIP Semarang

Dianita Wahyu (2010) Analisis Faktorfaktor yang Memotivasi Mahasiswa dalam Berwirausaha dengan Studi Kasus pada Universitas Muhamadiyah Malang. Sripsi UMM Malang

Didik Hariyanto, 2009, Analisa Faktorfaktor Yang Membentuk Jiwa Wirausaha Pengusaha di Wilayah Kecamatan Lowokwaru, Universitas Islam Negeri Malang.

Dollinger M. 1995. Entrepreneurship: Strategies And Resources. Irwin Publishing: Illinois.

Doughlas, E.J., \& Shepherd, D.A. 2002. Self-Employment as a Career Choice: Attitudes, Entrepreneurial Intentions, and Utility Maximization. Entrepreneurship Theory and Practice, 81-90.

Ee Ah Meng 1998. Pendidikan Di Malaysia Untuk Guru Pelatih (Edisi Kedua). Penerbit Fajar Bakti Sdn. Bhd.

Encik Bukryman Sabri, 2008, Penelitian Aspirasi Kewirausahaan Belia Terhadap Memupuk Budaya Kewirausahaan Ke Arah Menuju Berprestasi Wawasan 2020 Malaysian Institute for Research in Youth Development

Endang Mulyani, 2010, Pengembangan Pendidikan Kewirausahaan, Kementrian Pendidikan Nasional Badan Penelitian dan Pengembangan Pusat Kurikulum, Jakarta.

Ferdinand, Augusty, 2005, Structural Equation Modeling (Edisi 3), Semarang, CV. Indoprint.

Ferry Yang, 2008, Entrepreneur: Dilahirkan atau Diajarkan?, University of Ciputra Entrepreneurship Center, Jakarta.(Tue, 08/04/2008 - 11:05)

Francis, D.H dan Sandberg, W.R. 2000, 
"Friendship within entrepreneurial teams and its association with team and venture performance",

Entrepreneurship Theory and Practice, Vol.25 No.2, pp.5-26.

Frinces, Helfin, 2011, Be An Entrepreneur (Jadilah Seorang Wirausaha), Graha Ilmu, Jakarta.

Frinces, Helfin,, 2004, Kewirausahaan dan Inovasi Bisnis, Darussalam, Yogyakarta.

Gartner, W.B., Shaver, K.G. \& Gatewood.E.J.2000. Doing it for youself: Career Attributions of Nascent Entreprenenurs. http:www.NFIB paper.htm, (21.2.2011).

Gaulden, C. F. Jr., Jackson, W.T.,Gaster, W. (Buddy) \& Vaughan, M.J. 2004. Student Entrepreneurs: Regional Differences. http://www.sbaer. uca.edu/reseach/ asber/2004_fall/13.pdf. (10.5.2011).

Ghozali dan Fuad. 2008. SEM. Teori dan Konsep dengan Program LISREL 8.80. Semarang : BP-Undip. Page : 29 $-34$

Gelderen, M.V., Brand, M., Praag, M.V., Bodewes, W., Poutsma, E., \& Gils, A.V.2008. Explaining entrepreneurial intentions by means of the theory of planned behavioural. Career Development International, 13(6), 538-559.

Gibb, A. 1996. Do we really teach (approach) small business the way we should? Dlm. Low Aik Meng \& Tan wee Liang (pnyt.). Entrepreneurs, entrepreneurship and enterprising culture (hlm. 113-132). Singapore: Addison-Wesley Publishing Company.

Goleman, D. 1998. Working with emotional intelligenc'.New York: Bantam Books.

Greenberger, D.B. and Sexton, D.L. 2003, An Interactive Model Of New Venture Initiation. Journal of Small Business Management. 26 (3), 1-7.
Hair, J.F., Black W.C., Babin, B.J., Anderson, R.E\& Tatham, R.L. 2006. Multivariate Data Analysis. Edisi Keenam. New Jersey: Prentice Hall.

Hair, J.F., Babin B.; Money, A. H. \& Samouel, P. 2003. Essentials of Bussiness Research Methds. Hoboken. Jhon Wiley \& Sons Inc.

Halimah Harun., 2001. Budaya Kewirausahaan di Kalangan Mahasiswa Politeknik Malaysia, Bangi: Universiti Kebangsaan Malaysia.

Hasan Mohammad, 2007, Faktor-faktor yang talah Mendorong Alumni dan Alumni Universiti Teknologi Malaysia Menceburi Bidang Kewirausahaan, Fakulti Pengurusan dan Pembangunan Sumber Manusia, Universiti Teknologi

.Henderson, R. \& Robertson, M. 2000. Who wants to be an entrepreneur? Young Adult attitudes to entrepreneurship as a career. Career Development International, 5 (6), 279 287.

Henry, C., Hill, F. \& Leitch, C. 2003. Entrepreneurship Education and Training. Aldershot: Ashgate.

Hairunnaja Najmuddin, 2005. Membimbing Remaja Memilih Pendidikan \& Kerjaya. PTS Professional: Publishing Sdn. Bhd.

Helge Lo Bler, 2006, Learning Entrepreneurship from a Constructivist Perspective Technology Analysis \& Strategic Management Vol. 18, No. 1, 19-38, February 2006, University of Leipzig, Germany

Hisrich R.D. 2005. Entrepreneurship: Starting, Developing And Managing A New Enterprise. Irwin Publishing: Boston.

Hisyamudin Hasan, 2007, Hubungan Faktor Terpilih dengan Tekad Kewirausahaan Mengikut Persepsi Mahasiswa, Thesis Universiti Putra Malaysia.

Hendry, C., Hill F \& Leitch, C. 2003. Entrepreneurship Education and 
Training. Aldershot; Ashgate.

Imam Ghazali, 2002, Aplikasi Analisis Multivariat dengan Program SPSS, Semarang. Universitas Diponegoro.

Indarti,\& Rokhima Rostini, 2008, Intensi Kewirausahaan Mahasiswa: Studi Perbandingan Antara Indonesia, Jepang dan Norwegia, Jurnal Ekonomika dan Bisnis Indonesia, Vol. 23, No. 4, Oktober 2008

Isky Fadli Fu'adi,dkk, 2009, Hubungan Tekad Berwirausaha dengan Prestasi Praktik Kerja Industri Siswa Kelas XII Teknik Otomotif SMK Negeri 1 Adiwerna Kabupaten Tegal Tahun Ajaran 2008/2009. JURNAL PTM VOLUME 9, NO. 2, DESEMBER 2009

Issam, Ghazzawi, 2010, The Next Generation of Entrepreneurs: $a$ Reflevtion of College Uutreach Business Program for High School Students, Journal of Entrepreneurship Education, Volume 13, 2010

Jamil Ahmad. 2002. Pemupukan Bdaya Penelitian di Kalangan Guru di Sekolah:Satu Penilaian. Tesis Dr. Fak. Pendidikan Universiti Kebangsaan Malaysia.

Joo-Heon Lee \& Venkataraman, S. 2006. Aspirations, market Offerings, and the pursuit of entrepreneurial opportunities. Journal of Business Venturing. Vol 21: $107-123$.

Jones. M., 1990, Women In Enterprise: Partner by the year 2000?. Women in management review, pp 8-13

Juhary, Hj. Ali \& Ishak Ismail 1991. Prinsip dan Amalan Pengurusan. Kuala Lumpur: Dewan Bahasa dan Pustaka.

Kalafatis, S.P., Pollard, M., East, R. \& Tsogas, M.H. 1999. Green marketing and Ajzen's theory of planned behavior: a cross-market examination. Journal of Consumer Marketing, 16(5), 441-460.

Kartika Pritiwi, 2010, Peran Kewirausahaan bagi Pembangunan, http://kartikapradini- tika.blogspot.com/2010/10/perankewirausahaan-bagipembangunan.html, di akses 2 April 2011, jam 16.20.

Kamus Dwibahasa Oxford Fajar 1992. Kuala Lumpur. Penerbit Fajar Bakti Sdn. Bhd.

Kamus Dewan, 2007. Kuala Lumpur: Dewan Bahasa Dan Pustaka.

Khashiatul-Fauziah Binti Hamzah, 2003. Faktor-Faktor Yang Mempengaruhi Pemilihan Kerjaya Di Kalangan Remaja Melayu Di Daerah Batu Pahat." UTM: Tesis Sarjana Muda (Tidak diterbitkan).

Kirby D. 1992.Developing Graduate Entrepreneurs: Entrepreneurship, Innovation And Change. United Kingdom: The U.K. Enterprise.

Kristiansen, S., \& Indarti, N. 2004. Entrepreneurial Intention among Indonesian and Norwegian Students. Journal of Enterprising Culture, 12, 55-78.

Kolvereid, L., 1999. "Prediction of employment status choice intentions". Entrepreneurship Theory and Practice 21 (1): 47-57.

Kuratko, D. F. \& Hodgetts, R. M. 2004. Entrepreneurship: Theory, Process and Practice. 6. Ohio: South Western

Kurjono, 2009 Pengaruh Faktor Siswa, Kompetensi Guru danLingkungan Keluarga, Terhadap Sikap Kreatif dan Sikap Inovatif dan Implikasinya Terhadap Motivasi Kewirausahaan, Prodi Pendidikan Akuntansi UPI,

Kusnedi, 2010, Analisis Jalur dengan Amos, Rizqi Press, Bandung.

Lee, J., 1997. "The motivation of women entrepreneurs in Singapore". International Journal of Entrepreneurial Behaviour and Research 3 (2): 93-110.

Lena, L. \& Wong, P.K. (2003). Attitude Towards Entrepreneurship Education andNew Venture Creation. Journal of Enterprising Culture, 11(4), 339-357.

Lim Khong Chiu, 2009. University Student' Attitude, Self-Eficacy and 
Motivation Regarding Leisure Time Psysical Participation, Jurnal Pendidik dan Pendidikan, Jil. 24, 115, 2009

Linan, F., Urbano, D., \& Guerrero, M. 2007. Regional Variations in Entrepreneurial Cognitions: Start-up Intentions of University Students in Spain. Paper presented at the Babson Conference, Madrid, 2007.

Lobler, H. 2006. Learning entrepreneurship from a constructivist perspective. Technology Analysis \& Strategic Management. 18(1): 19-38.

Maag, J.W. 2004. Behavior Management : from Theoretical Implications to Practical Application. Edisi ke-2 California: Thomson Learning.

Mahmuddin, 2010, Faktor-faktor Pendorong Kewirapengusaha,

www.labschoolunj.sch.id/ smpjkt/materi_download. php?id=Desember 2010.

Mathews, C. H. dan S. B. Moser, 1996. " $A$ longitudinal investigation of the impact of family background and gender on interest in small firm ownership". Journal of Small Business Management 34 (2): 29-43.

Mazzarol, T., T. Volery, N. Doss, dan V. Thein, 1999. "Factors influencing small business start-ups". International Journal of Entrepreneurial Behaviour andResearch 5 (2): 48-63.

Marselia Herma, 2008, Pengaruh Kualitas Manajemen, Motivasi Kewirausahaan dan Pengelolaan Merek Terhadap Kualitas Hubungan Franchise dalam Meningkatkan Kinerja Penjualan (Studi Pada Perusahaan Franchise Di Kota Semarang Dan Yogyakarta) thesis PPS Universitas Diponegoro, Semarang.

Md. Mohar Mohamad dan Dr. Mohd Hassan Mohd Osman 2002. Menilai,Mengukuh dan Memantapkan Program Pembangunan Pengusaha Bumiputera di Negeri Johor Darul Takzim. Bengkel Masyarakat
Perdagangan dan Perindustrian Bumiputera Negeri Johor, Hotel Hyatt Regency, Johor Bahru.

Meeks, Micheal D. 2004 Antecedents of Entrepreneur Decision: An Empirical Analysis of Three Predictive Models. Unpublished PhD Dissertation, University of Michigan Ann Abor. University of Colorado at Boulder

Mery Citra, 2010, Mendorong Pilihan Karir Berwirausaha pada Mahasiswa guna mengentaskan Pengangguran Terdidik di Indonesia, pustaka. unpad.ac.id/ (di upload tgl 7 November 2011 pukul 21.00 WIB)

Mitchell, R. K., Bailey, A. \& Mitchell, J. R. 2008. Entrepreneurship, thinking, and economic self-reliance. ESR Review. 10(1): 8-13.

Muhammad Rashid Bin Rajuddin \& Eric Yeo Cheng Aun , 2009, Faktor-faktor yang mendorong Masysrakat Baba dan Nyonya di Bandar Melaka Menceburi Bidang Kewirausahaan, Fakulti Pendidikan, Universiti Teknologi Malaysia

Muhammad Haron Husaini \& Khairul Anuar Ahmad, 2008, Kemahiran Kewirausahaan: Satu Penelitian Analisis Kandungan Buku-buku Teks, Prosiding SKIKS 08

Munandar, Utami. 2002. Kreativitas dan Keberbakatan Strategi Mewujudkan Potensi Kreatif dan Bakat. http://www. maindexchange. com/ index2.php?option=com_ docman\& task=doc_view $\&=99 \&$ Itemid=28.

Moethya, 2010, Teori Mengenai Kreatifitas Posted in Pengembangan Kreatifitas Keberbakatan, Psychology, Teori Mengenai Kreatifitas www.labschoolunj.sch.id/ smpjkt/materi_download. php?id=7.

Mohd. Najib Abdul Ghafar. 2003. Reka Bentuk Tinjauan Soal Selidik Pendidikan. Skudai : Universiti Teknologi Malaysia.

Moh. Nazir, 2003. Metode Penelitian, 
Penerbit Ghalia Indonesia, Jakarta, 2003.

Mohd Salleh Din, Hoe Chee Hee, Norashidah Hasyim, Ooi Yeng Keat, Shuhymee Ahmad, Habshah Bakar, Norita eraman, Rosli Mahmood, Armanurah Mohamad, Lily Julienti Abu Bakar \& Momad Nasri Md Husen, 2005. Azas Kewirausahaan, Kuala Lumpur, Prentice Hall.

Norfadilah, 2010, Aspirasi Kerjaya Kewirausahaan dalam Kalangan Mahasiswa Institusi Perguruan Tinggi Awam (Entrepreneurial Career Aspirations Among IPTA Students) Jurnal Pendidikan Malaysia 35(1)(2010): 11-17

Noraziah Ali, Ranimah Yusuf \& Hasnah Ali,2008, Part-Time Working Trend Among the Secondary Students in the District of Melaka Tengah and its Implication to Their Learning Performance in School, Journal eBangi, Volume 3, BILANGAN 1, 12, 2008. ISSN: $1823-884 \mathrm{x}$

Nooraini Othman at al, 2009,Persepsi terhadap Faktor-Faktor Yang Mempengaruhi Minat Mahasiswa 4SPH dalam Bidang Kepengusaha Fakulti Pendidikan, Universiti Teknologi Malaysia

Norasmah Othman. 2002. Keberkesanan Program Kewirausahaan Remaja di Sekolah Menengah. Thesis Ph.D. Universiti Putera Malaysia.

Norasmah Othman, Norashidah Hasyim \& Noraisyah Buang 2009, Konsep Kesediaan Kewirausahaan Berdasarkan Penelitian Kes Pengusaha Industri Kecil dan Sederhana (IKS) di Malaysia (Entreprenuership Readiness Concept Based on Case Study of Small Medium Industry (SMI) Entrepreneurs in Malaysia)Jurnal Pendidikan Malaysia 34(1)(2009): $187-203$

Norasmah Othman, Halimah Harun \& Raden Siti Aisyah Raden A Rahman, 2011, Kewirausahaan Pemangkin Kecemerlangan Negara dan
Kelestarian Hidup, Fakulti Pendidikan Universiti Kebangsaan Malaysia, Bangi.

Norasmah Othman \& Muharam Gaya, 2009, Tahap Pengetahuan Pelatih Institut Kemahiran Mara Mengenai Persekitaran Kondusif Untuk Bakal Pengusaha, Jurnal Teknologi, 50(E) Jun 2009: 53-67 (C) Universiti Teknologi Malaysia

Norasmah Othman \& Halimah Harun, 2007, Keusahaan Remaja Malaysia, Penerbit Universiti Putera Malaysia

Norasyidah Bt Hasyim, 2009, Kesediaan Kewirausahaan Mahasiswa dan Persekitaran Dalaman Institusi Perguruan Tinggi Awam Malaysia Dalam Melaksanakan Pendidikan Kewirausahaan, Thesis Doktor Falsafah, Fakulti Pendidikan Universiiti Kebangsaan Malaysia.

Nor Aaishah Bt. Buang, 2008. Penelitian Keperluan Pendidikan Kewirausahaan Secara Formal Dalam Kalangan Mahasiswa Fakulti Kejuruteraan dan Alam Bina dan Fakulti Pendidikan, UKM, Fakulti Pendidikan, UKM

Nor Aishah Bt. Buang 2006, Prinsipprinsip Kewirausahaan, Konsep, Teori dan Model-model Pembentukan Wirapengusaha, Fakulti Pendidikan Universiti Kebangsaan Malaysia.

Nor Aishah Buang. 2002. Asas Kewirausahaan. Shah Alam: Penerbit Fajar Bakti.

Nurul Indarti dan Rokhima Rostiani, 2008, Intensi Kewirausahaan Mahasiswa: Studi Perbandingan Antara Indonesia, Jepang dan Norwegia, Jurusan Manajemen, Fakultas Ekonomi, Universitas Gadjah Mada, Jurnal Ekonomika dan Bisnis Indonesia, Vol. 23, No. 4, Oktober 2008

Purwanto, M. Ngalim, MP. 2004. Psikologi Pendidikan. Bandung : Remaja Rosda Karya

Rae, D. \& Carswell, M. 2000. Using a lifestory approach in entrepreneurial learning: the development of a conceptual model and its implications 
in the design of learning experiences. Education + Training. 42(4/5): 220-7.

Ramli , at al, 2006, Gaya Kepimpinan Pengetua Wanita dan Hubungannya dengan Tahap Motivasi Guru Sekolah Menengah Pengetuan Jurnal Pendidikan 31 (2006) 53 - 6953

Ramlee Mustapha, 2008, Promoting Human Capital Through Social Entrepreneurship: A Comparative Study of Indonesia and China, Jurnal Pendidikan.

Rasheed, H. \& Rasheed, B. 2003. Developing Entrepreneurial Characteristics in Youth: The Effects of Education and Enterprise Experience. Ethnic Entrepreneurship: Structure and Process, ed: Stile, C. \& Gabraith, C: Elsevier Science, Amsterdam.

Riyanti Dwi P Benedicta, 2003, Kewirausahaan dari Sudut Pandang Psikologi Kepribadian, Penerbit Grasindo, Jakarta.

Ronald El Walpole, 1992. Pengantar Statistika, Edisi ke-3, Penerbit PT Gramedia Pustaka Utama, Jakarta.

Santoso. 1993. Lingkungan Tempat Tinggal dalam Menentukan Minat Berwiraswasta FKIP UNS (Laporan Penelitian). Surakarta: UNS.

Salleh Amat , 2009, Hubungan antara Ketegasan Diri dan Kepuasan Hidup dalam Kalangan Mahasiswa Institusi Perguruan Tinggi (The Relationship between Assertiveness and Satisfaction with Life Among Students at a Higher Learning Institution) Jurnal Pendidikan Malaysia 34(2)(2009): $49-65$

Schiller, B.R., dan P. E. Crewson, 1997. "Entrepreneurial origins: a longitudinal inquiry". Economic Inquiry 35 (3): 523-531.

Segal, Gerry, Borgia, Dan and Jerry Schoenfeld, 2005, The motivation to become an entrepreneur, International Journal of Entrepreneurial Behaviour \&Research, Vol. 11 No. 1, 2005 pp. $42-57$
Sequeira, J. 2004. New Venture Intention of Female Nascent Entrepreneurs: Does Dentrepreneurial Self Efficacy and Sosial Network Matter? http://www.babson.edu/entrp/fer/FER 2004/web-content/section\% 20III/PSI/III-PS1_Text.. ( 3.9.2011)

Slameto. 2003. Belajar dan Faktor-faktor Yang Mempengaruhinya. Jakarta : Rineka Cipta

Sinha, T. N., 1996. "Human factors in entrepreneurship effectiveness". Journal of Entrepreneurship 5 (1):2329.

Siti Rahayan Arifin, at al, 2008, Faktor Kontribusi Kecerdasan Pelbagai dalam Kalangan Mahasiswa Remaja MahasiswaRemaja, Jakarta

Siti Hawa, (2009), Kecendrungan Kewirausahaan di kalangan Mahasiswa Bidang Kejuruteraan di Institusi Perguruan Tinggi Awam di Kawasan Utama Semenajung Malaysia. Projek Sarjana ini diserahkan kepada Kolej Perniagaan, Universiti Utara Malaysia,

Souitaris, V., Zerbinati, S. \& Al-Laham, A. (2007). Do entrepreneurship programmes raise entrepreneurial intention of science and engineering students? The effect of learning, inspiration and resources. Journal of Business Venturing, 22 (4), 566-591.

Subhash Sharma, 1996, Applied Multivariate Technique, fist edition Jhon Willey and Sons,inc Toronto,,

Sukarni, 2012, Konstribusi Jenis Kelamin, Usia, Tempat Tinggal, dan Tingkat Pendidikan Orang Tua terhadap minat berwirausaha mahasiswa FKIP UIR Pekanbaru, FKIP UIR Pekanbaru.

Sukarni, 2011, Pengaruh Element Pendukung Terhadap Minat Kewurausahaan Mahasiswa FKIP UIR Jurusan Pendidikan AKuntansi, Jurnal PeKA- FKIP UIR Vol. 1. No. O1, Januari 2013

Sukmana, UD, 2008, Peranan Pendidikan Kewirausahaan dalam Menumbuhkan Motivasi Wirausaha ( Studi Tentang 
Pengaruh Pendidikan Kewirausahaan Terhadap Motivasi Wirausaha Mahasiswa Universitas Kuningan, Equilibrium, Vol. 4, No 8, Juli Desember 2008.

Sunarya, Abas, 2011, Kewirausahaan, Andi Yogyakarta.

Suryaman, Maman. 2006. Minat Berwirausaha Pada Mahasiswa Pendidikan Teknik Elektro. Fakultas Teknik. Program Sarjana Universitas Negeri Semarang, Semarang.

Suryana, 2003, Kewirausahaan Pedoman Praktis, Kiatdan Proses Menuju Sukses, Penerbit Salemba Empat, Edisi Revisi, Jakarta.

Tan, W.L., Siew, L.K., Tan, W.H. \& Wong, S.C. (1995). Entrepreneurial Spirit Among Tertiary Students in Singapore. Journal of Enterprising Culture, 3 (2), 211-227.

Thomas, A.S. \& Muller, SL. (2000). A case for comparative entrepreneurship: assessing the relevance of culture. Journal of International Business Studies, 31(2), 287-305.

Tinambunan, Anita,P, 2010, Jalan Menuju Wirausaha Yang Sukses, Jurnal Media UnikaTahun 20 no 73 Edisike 4, Unika Jakarta.

Triyatna O S, 2009, Kepemimpinan Wirausaha, Rahasia Bertahan di tengah Krisis, Harian Kompas, Jumat 22 Mai 2009, Jakarta.

Tony Wijaya, 2007, Hubungan Adversity Intelligence dengan Intensi Berwirausaha (Studi Empiris pada Siswa SMKN 7 Yogyakarta), Jurnal Majanemen dan Kewirausahaan Vol 9 No 2 Sepetember, 2007

Thuaibah, 2007, Penglibatan Kaum Wanita Dalam Aktiviti Kewirausahaan di Negeri Johor: Penelitian Terhadap Faktor-Faktor Kritikal Kejayaan dan Kegagalan Pengendalian Perniagaan , Jabatan Pembangunan Sumber Manusia Fakulty Pengurusan dan Pembangunan Sumber Manusia, Universiti Teknologi Malaysia,
Valentiono Dinsi, Jangan Mau Seumur Hidup Jadi Orang Gajian, Letsgo Indonesia, 2004

Wiedy Murtini, 2008, Sucsess Story Sebagai Pendekatan Pembelajaran Kewirausahaan, Varia Pendidikan, Vol. 20, No. 2, Desember 2008

Winardi, 2003, Entrepreneur dan Entrepreneurship, Kencana, Jakarta.

Winarno, 2011, Pengembangan Sikap Entrepreneurship dan Intrapreneurship, PT Indeks, Jakarta.

Yohnson, 2003, Peranan Universitas Dalam Memotivasi Sarjana Menjadi Young Entrepreneurs, Jurnal Manajemen \& Kewirausahaan Vol. 5, No. 2, September 2003: $97-111$

Yusof, A.A., Perumal,S, 2005, Principles of Entrepreneurship, Person Perentice Hall, Selangor, Malaysia.

Yusof Bin Boon \& Sapiah Binti Bohari, (2009) Kesediaan untuk Menceburi Bidang Kewirausahaan di kalangan Mahasiswa mahasiswa Bumi Putera Tingkatan Empat di Tiga Buah Sekolah Sekitar Skudai, Johor, Fakulti Pendidikan, Universiti Teknologi Malaysia

Yusuf Kalla (2010) "Kemajuan Bangsa, Pendidikan dan Kewirausahaan" pidato ilmiah saat menerima gelar doktor kehormatan (Doctor Honoris Causa) daripada Universitas Pendidikan Indonesia (UPI) Bandung

Zaidatol Akmaliah Lope Pihie, 2009b, Entrepreneurship as a Career Choice: An Analysis of Entrepreneurial SelfEfficacy and Intention of University Students Faculty of educational studies,University Putra Malaysia, European Journal of Social Sciences Volume 9, Number 2 (2009) 338

Zaidatol Akmaliah Lope Pihie, Hassan Hisyamuddin, 2009b, Choice Of SelfEmployment Intention Among Secondary School Student, Uluslararasi Sosyal Ara_tırmalar Dergisi The Journal of International Social Research Volume 2 / 9 Fall 2009 
Zafir Mohd Makhbul dan Fazilah Mohamad Hasun (2003). Menjadi Pengusaha. PTS Publications \& Distributor Sdn. Bhd.

Zimmerer, W. T dan Sacrborough, N.M.
(1998). "Essential of Entrepreneurship and Small Business Management." New Jersey : Prentice Hall. 
